\title{
INFORMATION COMMUNICATION TECHNOLOGIES AS A SUPPORT STRATEGY FOR LEARNERS EXPERIENCING READING DIFFICULTIES
}

\author{
Shila Mphahlele \& Norma Nel \\ University of South Africa
}

One of the most significant current discussions in education departments around the world is reading difficulties. This article explores the use of information communication technologies (ICTs) to support learners experiencing reading difficulties in two public primary schools. For data collection purposes, a total of 18 school-based support team members and two learning support educators participated in this research through focus group interviews and observation. From the data collected, the teachers' perceptions, attitudes, understanding, knowledge, values, feelings and experiences were analysed. The study was influenced by Vygotsky's theory of cognitive development. From the findings, three themes were identified, namely, factors that contribute towards reading difficulties, the effects of reading difficulties and the effectiveness of ICTs in supporting learners experiencing reading difficulties. The most interesting finding was that ICTs as a support strategy proved to be vital in supporting learners experiencing reading difficulties.

Keywords: reading difficulties, information communication technologies, learning support educators, school-based support team, support strategy

\section{INTRODUCTION}

Reading difficulties are a global challenge and a policy imperative, and therefore received considerable critical attention during the United Nations (UN) Millennium Summit, held in New York in September 2000. World leaders at the summit committed their nations to a global partnership to reduce extreme poverty by setting out the Millennium Development Goals (MDGs) ${ }^{1}$ to be achieved by 2015 . The MDG relevant to this study is MDG 2: achieve universal primary education - a goal that will have been achieved only if all learners can read fluently and with comprehension (Gove \& Cvelich 2010). At the $70^{\text {th }}$ United Nations Assembly, held in September 2015, government leaders reviewed the progress of the MDGs and adopted 17 Sustainable Development Goals (SDGs) ${ }^{2}$ to be achieved by 2030. The SDG relevant to this study is SDG 4: quality education, which has as a primary aim to 'ensure inclusive and equitable quality education and promote lifelong learning opportunities for all' (UNESCO, 2015). In order to meet this goal, children need to be able to read and teachers worldwide need to commit to the quest to raise a reading nation.

Apart from being a global challenge, the concept of 'reading difficulties' is broadly perceived and very fluid in nature. Reading improves literacy levels, social skills and personal wellbeing, and provides meaningful activity and a sense of purpose (Evans \& Jones, 2011: 6). Akyol, Çakiroğlu and Kuruyer (2014) explain that reading difficulties can have an impact on a lot more than just the learner's schoolwork. It can also affect the person's self-esteem and social life. This is confirmed by recent studies by UNESCO (2015) and the National Research 
Council (NRC) (2010), which also draw attention to the fact that most learners across the globe are experiencing reading difficulties.

McArthur and Castles (2017:3) found evidence that there are learners experiencing reading difficulties who have been subjected to a variety of support strategies such as behavioural optometry, music, computer games, phonics, sensorimotor exercises, sound training, spatial frequency gratings, memory training, medication for the inner ear, phonemic awareness, rapid reading, visual word recognition and vocabulary training. A reading support strategy called Reading Strategy Instruction was also implemented in South African schools by Klapwijk (2012).

In order to make sense of the variety of support strategies that are recommended for learners experiencing reading difficulties, it may be helpful to use information communication technologies (ICTs), because they have become essential tools in the classroom. Before outlining the effectiveness of using ICTs as a support strategy for learners experiencing reading difficulties, this article begins by reflecting on the implications of reading difficulties globally, in sub-Saharan Africa and locally.

\section{IMPLICATIONS OF READING DIFFICULTIES GLOBALLY, IN SUB-SAHARAN AFRICA AND LOCALLY}

A study conducted by Balcaza (2014: 2) identified a number of learners who had dropped out of school due to their struggle to learn to read. Interestingly, Balcaza reports that learners who are not reading at a proficient level by fourth grade are four times more likely to drop out of high school before graduating. Morrisroe (2014: 6-7) maintains that the ultimate results for learners who experience reading difficulties are unemployment, poverty and criminal convictions.

The aforementioned implications are supported by data presented by the UNESCO Institute for Statistics (UIS, 2015) regarding learners around the globe who are unable to achieve minimum proficiency levels in reading. The UIS (2015) also presents statistics of children who are out of school. As outlined by UIS (2015), during the school year 2013, 124 million children and young adolescents between the ages of six and 15 years either never started school or dropped out. In 2015, approximately 264 million children were out of school. Looking at the 2013 numbers, it is evident that there was a 50\% increase between 2013 and 2015. Sadly, the number almost tripled in 2017, with 617 million children and adolescents reportedly unable to achieve minimum proficiency levels.

Against this backdrop, it can be concluded that reading difficulties can threaten progress towards the achievement of the SDGs mentioned in the introduction, and urgent support is needed for learners experiencing reading difficulties in an effort to achieve these SDGs. In addition, more than $50 \%$ of the 617 million children mentioned above might not be able to read with proficiency by the time they are of age to complete primary education. The proportion is even higher for adolescents, with $61 \%$ unable to achieve minimum proficiency levels when they should be completing lower secondary school (UIS, 2017).

In the section that follows, reading difficulties are discussed as a widespread phenomenon that has considerable impact on teaching and learning. The argument is based on the systemic evaluation reports that are written frequently in order to compare levels of national achievement between countries to identify the major determinants of national achievement, to 
examine the extent to which levels are the same or differ across countries, and to identify factors that affect differences between countries (Plomp, Anderson, Law \& Quale, 2009:12). There is some evidence to suggest that these systemic evaluations also assist ministries of education to share their experiences and to learn from each other (Organisation for Economic Cooperation and Development (OECD), 2017: 10).

\section{The systemic evaluation reports}

The systemic evaluation reports relevant to this study are as follows: Progress in International Reading Literacy (PIRLS, 2016), the Programme for International Student Assessment (PISA, 2015) and the sub-Saharan Africa, the Southern and Eastern Africa Consortium for Monitoring Education Quality (SACMEQ, 2016). The context within which this case study is situated is influenced by the implications of reading difficulties for learners from a global, sub-Saharan African and local perspective.

PIRLS (2016) indicates that there is still much to be done to reach MDG 2: education for all, as none of the countries in sub-Saharan Africa were able to reach global education goals by 2015. In the report, it was found that three-quarters of South African learners were not able to reach the lowest international benchmarks and only two percent could reach the highest international benchmark.

The PISA (2015) report revealed that $20 \%$ of learners in OECD countries, on average, did not attain the baseline level of proficiency in reading. The OECD countries involved included, among others: Argentina, Belgium, Canada, Denmark, Hong Kong (China), Iceland, the Netherlands, New Zealand, Poland, Qatar, Spain, Sweden, Tunisia, the United Kingdom and the United States of America.

The SACMEQ (2016) report illustrated the survey results of SACMEQ IV, which was conducted in 2013. Contrary to the PIRLS and PISA reports, the SACMEQ IV report indicates that, since 2006, there has been improvement in the reading levels of the learners. Although the improvement is slight and slow, it is worth noting. The report also revealed that the number of learners with acceptable reading skills in South Africa had been $51.7 \%$ in SACMEQ III, and the number increased to $55.8 \%$ during the SACMEQ IV study.

\section{PERSPECTIVES ON READING DIFFICULTIES IN SOUTH AFRICA}

There is some evidence from researchers such as Moonsamy and Durbach (2016), Gunning (2010), and Shanker and Cockrum (2009) to suggest that specific reading difficulties experienced by learners in South Africa are, among others, poor phonics skills, poor comprehension, limited vocabulary, poor spelling and slow processing of words. The literature on South African reading difficulties highlights its uniqueness among other African countries in that less than half of its primary school learners learn to read for meaning in their mother tongue in lower primary school. That being the case, South Africa still experiences a problem with learners who are not able to read in lower primary school.

After further analysis of PIRLS 2016, The Centre for Evaluation and Assessment revealed that almost $78 \%$ of South African Grade 4 learners were not able to reach the lowest benchmark of the study (Howie, Combrinck, Roux, Tshele, Mokoena \& McLeod Palane, 2017: 4). 
Pretorius and Klapwijk (2017: 1) conducted a number of investigations into South African learners' reading difficulties, and one of the remarkable findings is that effective literacy instruction is inked to teachers' own reading habits. This finding coincides with Spaull's (2016: 2) finding that South African learners never get a firm hold on this first rung of the academic ladder (which in this instance is the foundation phase - Grades 1-3). They are perpetually stumbling forward into new grades, even as they fall further and further behind in the curriculum.

The study conducted by Pretorius, Jackson, McKay, Murray and Spaull (2016), among others, revealed that reading difficulties are an outcome of teachers who do not know how to teach reading. In addition, Pretorius and Klapwijk (2017: 1) highlight that there are fewer detailed descriptions of instructional practices and of what teachers are actually doing in their classroom. Spaull (2016) also stresses that pre- and in-service courses on teaching reading are unsystematic, inadequate or non-existent.

\section{SUPPORTING LEARNERS EXPERIENCING READING DIFFICULTIES}

A considerable amount of literature from sources such as Jennings, Schudt Caldwell and Lerner (2010), Rasinski, Padak and Fawcett (2010), and Gunning (2013), to mention but a few, has been published on reading difficulties support strategies, such as response to intervention, collaborative co-teaching and ICTs for learners experiencing reading difficulties. On the other hand, studies conducted by researchers such as Kirk, Gallergher, Anastasiow and Coleman (2012) have revealed that teachers use a variety and relevant teaching materials (visual, audio and kinaesthetic) in order to meet the diverse needs of learners experiencing reading difficulties. Another kind of support that was found in the study was parental involvement in the learning of learners experiencing reading difficulties. It was shown beyond a reasonable doubt that parental involvement (providing reading materials and attending school parent meetings) promotes the school-home relationship and the continuity of schoolwork to homework, under supervision. It also creates a good rapport between the parent and the child.

Another study conducted by Ogano (2012: 54) revealed that teachers in Norwegian schools use the method called the withdrawal method, whereby they remove learners experiencing reading difficulties from the classroom and take them to a resource room for what they call remedial work. The withdrawal method works exactly the same way as the one used by learning support educators in Gauteng, South Africa, called the 'pull-out system' (Gauteng Department of Education, 2014: 2).

A recent study by Salako (2014: 68) found that, in some parts of the world, such as the Czech Republic and Scotland, teachers use a learner-centred approach, which includes peer support, cooperative learning and scaffolding. In South African schools in the North West province, the Early Grade Reading Study was conducted by Taylor, Fleisch and Mahohlwane (2016). The study revealed that coaching intervention and parental involvement can lead to at least $40 \%$ reading improvement in the Setswana language for Grade 1 and 2 learners.

It is, however, a matter of concern that reading difficulties persist despite the use of various methods and approaches, such as those mentioned above, to support learners who are experiencing reading difficulties. In response to this dire situation, the authors of this article were propelled to explore the effectiveness of ICTs as a support strategy for learners experiencing reading difficulties (based on the discussion of the advantages of the use of ICTs 
in the section below). This led to the formulation of the research question: 'What significance can the use of ICTs have, as a learning support strategy for learners experiencing reading difficulties, in the intermediate phase?'

\section{ICTs as a support strategy for learners experiencing reading difficulties}

ICT is fast becoming a key instrument in addressing reading difficulties such as poor phonics skills, poor comprehension, limited vocabulary, poor spelling and slow processing of words. This statement is supported by the study conducted by Mosito, Warnick and Esambe (2017: 3), which uncovered that reading-to-speech technology, supportive e-text and electronic books can enhance the reading abilities of learners with intellectual impairments through computer technology. Even though the focus of this case study is not on learners with intellectual impairments, it is worth acknowledging the effectiveness of ICTs as a support strategy to a variety of learning barriers such as intellectual impairment.

Another study, by Amin (2013: 38), found that ICTs can enhance the teaching and learning process, as well as the quality and accessibility of education, the learning environment, learning motivation and scholastic performance. The conclusions of this study indicated that ICT can affect the delivery of education and enable wider access to the same. In addition, it will increase flexibility so that learners can access education regardless of time and geographical barriers. It can influence the way learners are taught and how they learn (Amin, 2013: 40). The findings of this study brought us to the safe conclusion that ICTs can influence the way learners learn to read.

The literature on integration of ICTs in the classroom, as confirmed by Ghavifekr and Rosdy (2015: 189), highlights effectiveness with regard to several aspects, such as enhancing learner collaborative learning skills as well as developing transversal skills that stimulate social skills, problem-solving, self-reliance, responsibility and the capacity for reflection and initiative. Their study proved that learners learn more effectively with the use of ICTs, as the lessons are more engaging and interesting.

\section{THEORETICAL FRAMEWORK: VYGOTSKY'S SOCIOCULTURAL THEORY}

According to Davison (2011: 1), the way children learn and mentally grow plays a central role in their learning processes and abilities. There is some evidence to suggest that several concepts arising from Vygotsky's theory of cognitive development are important to classroom learning. For the purpose of this study, we focused on two concepts: the zone of proximal development (ZPD) and scaffolding.

The ZPD is defined as the range of tasks that a learner can perform with collaboration, direction or some kind of help, to do more and solve more difficult tasks independently (Vygotsky, 1987: 209). Scaffolding, as the second concept of focus, is defined as a key feature of effective teaching and can include modelling a skill, providing hints or cues and adapting material or activities. Based on the definitions mentioned above, we conclude that scaffolding is directly related to ZPD in that it is the support strategy that helps a learner successfully perform a task within his or her ZPD. Vygotsky further highlights that the sociocultural environment presents learners with demands and engages learners in their world through the tools, which are ICTs in the context of this study. 
The relevance of ZPD and scaffolding in this study is the fact that, when Vygotsky (1987) proposed ZPD and the idea of 'scaffolding' in a learner's development, he recognised that there are some things learners cannot do independently (such as learning how to read), but that they would be able to do so with the assistance of someone else (Farr, 2014: 2) using ICTs during scaffolding.

\section{RESEARCH METHODOLOGY}

A case study design was selected in order to conceptualise reading difficulties and to explore how teachers use ICTs to support learners who are experiencing reading difficulties in two public primary schools. A qualitative approach was selected, whereby an inquiry takes place in which researchers collect data in face-to-face situations by interacting with selected persons in their setting (MacMillan \& Schumacher 2010:315). For this purpose, a case study was selected to gain a first-hand, holistic understanding of the use of ICTs to support learners experiencing reading difficulties.

\section{Selection of schools}

The case study was conducted in two primary schools in the Tshwane South District of Gauteng. One school (School A) is in an urban settlement (in the context of South African education, this school is called a 'former Model C school') where there are many resources. The other school (School B) is situated in a township where there are limited resources. Despite the differences in resources, the two schools experience similar challenges in respect of reading difficulties, something that appears to be a global challenge - hence the choice of these schools.

\section{Teacher participant selection}

In this case study, a non-probability sampling technique was employed. This refers to any technique in which samples are selected in some way not suggested by probability, because the odds of selecting a particular individual are not known. Most importantly, this sampling technique was selected based on which sample would be the most useful or representative (Babbie, 2010: 192-193). The teacher participants for this case study were 18 school-based support team (SBST) ${ }^{3}$ members and two learning support educators (LSEs). ${ }^{4}$ The reasons for these choices were that learners experiencing reading difficulties and other barriers to learning in schools are referred to members of both these groups for support, as well as the knowledge of the SBST and LSEs and their line functions.

Permission was obtained from the Gauteng Department of Education, principals of the schools, and the SBST and LSEs who participated in the research. Participants were briefed on the aim of the study, assured of confidentiality (by ensuring that their identities would not be divulged) and informed that they were under no obligation and could withdraw at any given time. The participants were also assured that the results of the research would be recorded as accurately as possible, and reflected and recorded in an article for publication in an accredited journal.

An application for ethical clearance was obtained from the Research Ethics Committee of the University of South Africa and from the Gauteng Department of Education. To ensure the reliability and trustworthiness of data, member checking (for trustworthiness) and triangulation (to control bias and establish valid propositions) were utilised (Creswell \& 
Miller, 2000: 126). Triangulation was possible due to the fact that multiple qualitative data collection strategies were employed. Strategies included one-on-one interviews with the LSEs, focus group interviews with the SBST members and observations to build a coherent justification for themes (Creswell, 2014: 201).

\section{DATA COLLECTION}

Data for the case study were collected by means of interviews (both individual and focus groups) with SBST members and LSEs, as well as observations of ICTs reading support lessons. One-on-one semi-structured interviews were held with the LSEs, because they were servicing a cluster of schools. Focus group interviews were held with SBST members in order to gain a shared understanding and to encourage participants to share their perceptions, points of view, experiences, wishes and concerns without pressure (Greeff, 2011: 362). School A has a reading class equipped with ICTs and School B has a computer laboratory with computers and television. Observations were made in the reading class and computer laboratory.

\section{DATA ANALYSIS}

The recorded data from the interviews and observations were transcribed electronically and organised in a matrix (or table), a form chosen from the three possible forms of organising data (Creswell, 2012: 238). For this case study, a matrix ${ }^{5}$ was developed to help organise data, condense them into simple categories and to summarise what the participants said or did, as themes could not be easily identified. However, through the use of this process, themes eventually emerged.

The organised data were analysed based on how participants made meaning of the use of ICTs. This was done through analysing their perceptions, attitudes, understanding, knowledge, values, feelings and experiences in supporting learners experiencing reading difficulties. The following themes emerged sequentially and are discussed in the section below: factors contributing towards reading difficulties, the effects of reading difficulties and the effectiveness of using ICTs as a support strategy.

Participants in the focus groups of both schools were given pseudonyms to ensure anonymity: Teacher A to Teacher F, and LSE1 (from School A) and LSE2 (from School B). The discussion of the findings below contains quotes from participants under abbreviated versions of these pseudonyms, for example, Teacher A = TA. School A was represented by focus group 1 (Sch.A) and school B by focus group 2 (Sch.B).

\section{DISCUSSION OF FINDINGS}

As indicated above, three themes emerged from the analysis of the focus group interviews, one-on-one interviews and observation.

\section{Theme 1: Factors contributing towards reading difficulties}

\section{Early identification}

From the findings, it was discovered that one of the factors contributing towards reading difficulties was the fact that this problem was not identified as early as required by the Screening Identification Assessment and Support ${ }^{6}$ policy framework. This finding is supported by the views of Gunning (2013: 28) and Rasinski et al. (2010: 16), who emphasise that, if learners who are experiencing reading difficulties are not identified early, the

Per Linguam 2018 34(2):1-13

http://dx.doi.org/10.5785/34-2-807 
effectiveness of reading support strategies such as response to intervention may be compromised. In addition, Lyytinen and Erskine (2016: 1) stress that, if left untreated, reading difficulties compromise knowledge acquisition, expose a child to repeated experiences of failure, and may thus reduce motivation for learning in general.

According to the participants, when learners experiencing reading difficulties were not identified early, their overall academic progress was affected, as the curriculum became more demanding for them. One participant maintained:

Mhm. Um - pertaining to reading in the first place, if it's diagnosed early enough um - I think it can be rectified. (LSE1)

The participants pointed out that they were given work schedules to complete within a term. The focus was thus mainly on covering the scheduled work, which made great demands on the learners, particularly those who experienced reading difficulties.

The participant who was observed was asked how she determined the kind and the level of ICTs support to provide to the learners experiencing reading difficulties. She responded by saying:

Ja, I identify them. I use...spelling test at the beginning of the year. You get it on the internet as well as Bird's Reading Test to get their reading and spelling ages.

\section{Language barriers}

Another factor that emerged as a contributing factor to reading difficulties was language barriers. It was established that, in both the schools, the language of learning and teaching was English, which was an additional language to most of the learners. Thus, the majority of learners experienced reading difficulties due to difficulty in acquiring the English language.

Their English and standard of communication are very poor. So, it's very difficult to teach a child to read if they don't even have the ability to communicate with you. (TE: Sch.A)

The literature pertaining to other sources of reading difficulties, as confirmed by Gillet, Tempel, Tempel and Crawford (2012: 443), denotes that learners with language difficulties will almost certainly have difficulty with reading due to challenges in retrieving words and, as a result, they may struggle to recall the names of objects or describing words.

During the observation, it was apparent that learners who experienced reading difficulties due to language barriers were able to benefit from the use of ICTs, because they could see the words and pictures representing the words projected on the interactive whiteboard. At the same time, the words were read back to them for the correct pronunciation.

\section{Limited teaching and learning resources}

When alluding to the challenge of limited resources, FG2 members became very emotional and added the challenge of limited access to teacher training to list.

...those learners cannot read. That is painful to be less trained...also without resources. You know ... [crying] you-you know? (TC: Sch.B). 
Teaching and learning resources, as explained by Okongo, Ngao, Rop and Nyongesa (2015: 132), refer not only to teaching methods and materials, but also the time available for instruction and the knowledge and skills of the teachers, which are acquired through training and experience.

If there's a projector, you find that it's only one. ...That's the problem, because we don't have these facilities. (TE: Sch.B)

The limited ICTs, especially in School B, contributed to the growing rate of learners with reading difficulties because teachers were unable to support all the learners.

\section{Theme 2: Effects of reading difficulties}

The participants indicated that the effects of reading difficulties were identified in the behaviour of the learners.

.... if a learner doesn't know how to read...the learner becomes withdrawn. He loses confidence, they don't have confidence in themselves and they end up being very shy. (TF: Sch.B)

Another participant from the first focus group touched on the issue of academic performance, self-esteem and the possibility of learners dropping out.

...that causes poor marks...it affects their self-esteem...in some cases, a possibility is that they can drop out. (TA: Sch.A)

The effects of reading difficulties mentioned by participants in this case study relate to Yamashita and Hayashi's (2014: 221) finding that reading difficulties decreased scholastic self-evaluation. In addition, a study by Karanja (2015: 70) found that learners experiencing reading difficulties tended to drop out of school or repeat grades, and some embarked on chronic absenteeism. Karanja's (2015) study further concluded that learners experiencing reading difficulties tended to have low self-esteem and perceived themselves as less valued members of their classes.

\section{Theme 3: Effectiveness of using ICTs as a support strategy}

During the observation of the practical ICT support lesson, Vygotsky's theory of cognitive development (discussed above) was evident. Some of the participants created the ZPD, coupled with scaffolding, during the support lesson, as indicated in the quote below. The learners ranged from those who refused to read to those who had come from other countries, where they had never used English to communicate or in their learning.

...those who have reading difficulties, we have to start with pictures then we introduce the letters gradually...so, if the children read and see pictures on the computer-umelectronic/interactive books make reading very easier for them. (LSE2)

It was apparent from the participants' responses and expressions that they had determination and passion in supporting learners experiencing reading difficulties. However, they raised concerns regarding the limited availability of ICTs as a resource for learner support, as well as a lack of or inadequate learner support training. A participant shared her frustration, stating that: 
I have a computer in my classroom with - uh - basic programs...so, when I do remedial, I will let one child sit for a few minutes doing compound words or whatever it is on - on a program in the classroom. (TA: Sch.B)

Participants' responses regarding the use of ICTs showed some passion, despite their limited ICT resources. LSE1 said that she used whatever limited material was available to her to develop an interest in reading in learners - for example, she would use computers at her disposal to surf the internet and she used the information from the websites mainly to capacitate the SBST members, in order to support the learners experiencing reading difficulties:

I use internet-based learning a lot. I use websites and I observe learners in a play - in a situation where they play, with games. Reading games - um - spelling games, okay we're not talking about spelling; we're only talking about reading. I've got excellent websites on their level, but contextual. (LSE1)

The participants also mentioned that they made use of radios and tape recorders. In addition, for audio-visual activities, they made use of television, though some of the participants discouraged the use of televisions as the learners sometimes became passive participants.

...tape recorders, we sometimes use them for the rhymes... (TE: Sch.A)

...even if when maybe you use TV, so that they watch something there, they just watch for the sake of watching. (TB: Sch.B)

During observations in the reading laboratory of School A, we noticed the use of interactive whiteboards, e-beams, various reading software and technological pens. Learners were interacting with the devices, showing interest and excitement. They used devices to form, read and view words and pictures. Most importantly, they could hear the correct pronunciation from the interactive white board and, ultimately, they were able to write what they had learned.

\section{CONCLUSION}

The discussions on the global context of reading difficulties have indicated that reading difficulties are indeed a global challenge. It is also evident that different countries around the world use a variety of support strategies to address reading difficulties and that, mostly, they use ICTs solely for teaching and learning. In the light of this, a pertinent issue that surfaced in this case study was the matter of insufficient ICTs in the schools and inadequate teacher training regarding the use of ICTs as a support strategy. The outcomes of this case study, as per the emerged themes, revealed the following:

- ICTs work well in identifying the specific reading difficulties and reading levels of learners; however, there should be sufficient ICTs to accommodate the majority of learners.

- Learners experiencing reading difficulties due to language barriers are well supported with ICTs.

- ICTs increase scholastic performance, flexibility and stimulation of social skills for learners who lost their self-esteem due to reading difficulties. 
In conclusion, ICTs as support strategy in classroom teaching and learning change the process and nature of learning positively, as confirmed by the literature consulted in this study. With that in mind, it is worth concluding that the use of ICTs is vital when they are employed as a support strategy for learners experiencing reading difficulties - as evidenced in School A, where ICTs were sufficient. This means that learners' different learning competencies are harnessed when using ICTs as a support strategy and, as a result, every learner experiencing reading difficulties can benefit from relevant support.

\section{ENDNOTES}

\footnotetext{
${ }^{1}$ The MDGs are the eight international development goals for the year 2015 that were established following the Millennium Summit of the United Nations in 2000, following the adoption of the United Nations Millennium Declaration (United Nations, 2015).

2 The SDGs are a set of 17 aspirational 'Global Goals' with 169 targets between them. Spearheaded by the United Nations, through a deliberative process involving its 193 member states, as well as global civil society, the goals are contained in paragraph 54 of United Nations Resolution A/RES/70/1 of 25 September 2015.

${ }^{3}$ The school-based support team is the structure that supports the teaching and learning process by identifying and addressing learner, teacher and school's needs (Department of Education, 2001: 29).

${ }^{4}$ LSEs are teachers employed at the district level, but based at the schools, to provide support to the ILST, and serve as a link between schools and the district office (Department of Education, 2001: 47).

5 A matrix is a data display format that enables the researcher to understand the flow of events and their connection (Welman, Kruger \& Mitchell, 2011: 219).

${ }^{6}$ The screening, identification, assessment and support policy provides standardised procedures for supporting learners, to ensure that ALL children may access quality education and achieve to the best of their ability (Department of Education, 2014).
}

\section{REFERENCES}

AKYOL, H, A ÇAKIROĞLU \& HG KURUYER. 2014. A study on the development of reading skills of the students having difficulty in reading: Enrichment Reading Program. International Electronic Journal of Elementary Education, 6(2):199-212.

AMIN, S. 2013. An effective use of ICT for education and learning by drawing on worldwide knowledge, research and experience: ICT as a change agent for education (a literature review). Scholarly Journal of Education, 2(4):38-45.

BABBIE, E. 2010. The practice of social research (international ed.). Australia: Wadsworth Cengage.

BALCAZAR, S. 2014. Early literacy intervention strategies help prevent high school dropout: campaigning to boost high school graduation rates. Available from https://readingpartners.org/the-literacy-challenge/ [Accessed: 12 May 2015].

CRESWELL, JW. 2012. Educational research: planning, conducting, and evaluating qualitative and quantitative research. Boston, MA: Sage.

CRESWELL, JW. 2014. Research design: qualitative, quantitative, and mixed methods approaches. California: SAGE.

CRESWELL, JW \& DL MILLER. 2000. Determining validity in qualitative inquiry. Theory into Practice, 39(3):124-131

DAVISON, B. 2011. Piaget vs. Vygotsky: the cognitive development theory. Available from http://mrspurdyhilhi.weebly.com/uploads/1/5/1/4/15144774/vygotskyarticle.pdf [Accessed: 15 January 2018].

DEPARTMENT OF EDUCATION. 2001. White paper 6: special needs education: building an inclusive education and training system. Pretoria: Government Printers. Available from https://www.vvob.be/files/publicaties/rsa education white paper_6.pdf [Accessed: 12 May 2015].

Per Linguam 2018 34(2):1-13

http://dx.doi.org/10.5785/34-2-807 
DEPARTMENT OF EDUCATION. 2014. Policy on screening, identification, assessment and support. Pretoria: Government Printers.

EVANS, G \& A JONES. 2011. The importance of reading. Available from http://goscl.com/wpcontent/uploads/ImportanceOfReadingSCLWales.pdf [Accessed: 6 February 2016].

FARR, T. 2014. Vygotsky's theory of cognitive development. Available from https://blog.udemy.com/vygotskys-theory-of-cognitive-development/ [Accessed: 26 February 2017].

GAUTENG DEPARTMENT OF EDUCATION. 2014. Roles and responsibilities of learning support educators. Pretoria: Government Printers.

GHAVIFEKR, S \& W ROSDY. 2015, Teaching and learning with technology: effectiveness of ICT integration in schools. International Journal of Research in Education and Science, 1(2):175191.

GILLET, JW, CA TEMPLE, C TEMPLE \& A CRAWFORD. 2012. Understanding reading problems: assessment and instruction (8th ed.). North Carolina: Pearson.

GOVE, A \& P CVELICH. 2010. Early reading: igniting education for all: a report by the Early Grades Learning Community of Practice. Research Triangle Park, NC: Research Triangle Institute.

GREEFF, M. 2011. Information collection: interviewing. In AS de Vos, H Strydom, CB Fouchè \& CSL Delport (Eds), Research at grass roots. Pretoria: Van Schaik.

GUNNING, TG. 2010. Assessing and correcting reading and writing difficulties. Canada: Pearson.

HOWIE, SJ, C COMBRINCK, K ROUX, M TSHELE,GM MOKOENA \& N MCLEOD PALANE. 2017. PIRLS LITERACY 2016: South African highlights report. Pretoria: Centre for Evaluation and Assessment.

JENNINGS, JH, J SCHUDT CALDWELL \& JW LERNER. 2010. Reading problems: assessment and teaching strategies. Boston, MA: Pearson.

KARANJA, W. 2015. Effects of reading difficulties on academic performance among form three students in public secondary schools. Nairobi: Kenyatta University.

KIRK, G, J GALLERGHER, N ANASTASIOW \& M COLEMAN. 2008. Educating exceptional children. New York: Houghton Mifflin.

KLAPWIJK, NM. 2012. Reading strategy instruction and teacher change: implications for teacher training, South African Journal of Education, 32(2):191-204.

LYYTINEN, H \& J ERSKINE. 2016. Early identification and prevention of reading problems. In Encyclopedia on early childhood development. Available from www.childencyclopedia.com/sites/default/files/textes-experts/en/897/early-identification-and-preventionof-reading-problems.pdf [Accessed: 26 February 2018].

McARTHUR, G \& A CASTLES. 2017. Helping children with reading difficulties: some things we have learned so far. Science of Learning, 2(7):1-4.

McMILLAN, H \& S SCHUMACHER. 2010. Research in education: evidence-based inquiry. Boston, MA: Pearson.

MORRISROE, J. 2014. Literacy changes lives 2014: a new perspective on health, employment and crime. London: National Literacy Trust.

MOSITO, CP, AM WARNICK \& EE ESAMBE. 2017. Enhancing reading abilities of learners with intellectual impairments through computer technology. African Journal of Disability, 1(6):1-10.

OECD. 2017. PISA 2015 results (volume V): collaborative problem solving. Paris: OECD.

OGANO, JA. 2012. Teaching learners with reading and writing problems in the classroom: an interview study with teachers in Norwegian schools. Norway: University of Oslo.

OKONGO, R, G NGAO, N ROP \& W NYONGESA. 2015. Effect of availability of teaching and learning resources on the implementation of inclusive education in pre-school centers in Nyamira North Sub-County, Nyamira County, Kenya. Journal of Education and Practice, 6(35):132-141.

PLOMP, T, RE ANDERSON, N LAW \& A QUALE. 2009. Cross-national information and communication technology: policies and practices in education. USA: Information Age Printing. 
PRETORIUS, EJ \& NM KLAPWIJK. 2016. Reading comprehension in South African schools: are teachers getting it and getting it right? Per Linguam, 32(1):1-20.

PRETORIUS, E, M JACKSON, V MCKAY, S MURRAY \& N SPAULL. 2016. Teaching reading (and writing) in the foundation phase: a concept note. Available from http://resep.sun.ac.za/wp-content/uploads/2016/05/RESEPp_Zenex-TeachingReadingWriting Email.pdf [Accessed: 12 January 2018].

RASINSKI, TV, ND PADAK \& G FAWCETT. 2010. Teaching children who find reading difficult. Boston, MA: Allyn \& Bacon.

SALAKO, OO. 2014. Supporting teaching strategies in facilitating instruction for learners with learning difficulties (linking theory and practice): case studies of Czech Republic and Scotland inclusive primary schools. London: University of Roehampton.

SPAULL, N. 2012. SACMEQ at glance series: research on socio-economic policy. Pretoria: Department of Basic Education. Available from http://resep.sun.ac.za/index.php/projects/ [Accessed: 12 April 2015].

TAYLOR, S, B FLEISH \& M MAHOHKWANE. 2016. Early grade reading in South Africa: lessons from a large-scale intervention. Available from https://www.zenexfoundation.org.za/images/Early_grade_reading.pdf [Accessed: 8 June 2018].

UNESCO. 2015. Adult and youth literacy. Canada: Institute for Statistics. Available from http://www.uis.unesco.org/data/atlas-literacy/en [Accessed: 19 November 2015].

UNESCO INSTITUTE FOR STATISTICS. 2015. The EFA global monitoring report. Available from http://unesdoc.unesco.org/images/0023/002322/232205e.pdf [Accessed: 16 October 2017].

UNITED NATIONS, DEPARTMENT OF ECONOMIC AND SOCIAL AFFAIRS, POPULATION DIVISION. 2015. World population prospects: the 2015 revision, key findings and advance tables. Available

from https://esa.un.org/unpd/wpp/publications/files/key_findings_wpp_2015.pdf $\quad$ [Accessed: 15 January 2015].

VYGOTSKY, LS. 1987. Thinking and speech (translated by N Minick). In RW Rieber \& AS Carton (Eds), The collected works of LS Vygotsky: problems of general psychology. New York, NY, US: Plenum Press. 1(1): 39-285.

WELMAN, JC, SJ KRUGER \& B MITCHEL. 2011. Research methodology. Cape Town: Oxford University Press.

YAMASHITA, T \& T HAYASHI. 2014. [Effects of reading difficulties on scholastic self-evaluation and mental health in elementary school children]. No To Hattatsu = Brain And Development, 46(3):221-225.

\section{BIOGRAPHICAL NOTES}

Shila Mphahlele is a Lecturer at the University of South Africa (Unisa). She supervises Masters students and is currently editing a research book titled: Empowering students and ensuring inclusiveness and equality through ICT.

Norma Nel is a Professor Emeritus, Research Fellow and NRF grant holder at Unisa. She supervises Masters and Doctoral students. She is currently involved in international collaborative research on ESL/EFL in Chinese contexts. 